\title{
PROBLEM-BASED LEARNING TO IMPROVE PROBLEM- SOLVING SKILL: IS IT EFFECTIVE ENOUGH?
}

\author{
Ardian Asyhari ${ }^{1^{*}}$, Muhammad Sifa'i' ${ }^{2}$, \\ ${ }^{1}$ Department of Physics Education, Universitas Islam Negeri Raden Intan Lampung, Indonesia \\ ${ }^{2}$ SMA N 1 Ulubelu, Lampung Indonesia
}

*Corresponding author: ardianasyhari@radenintan.ac.id

\begin{tabular}{|c|c|}
\hline Article & ABSTRACT \\
\hline Article hi & \multirow{8}{*}{$\begin{array}{l}\text { This study aimed to determine the effectiveness of the problem } \\
\text { based learning model on the problem solving ability of high school } \\
\text { students. This research is a quasy experimental research with the } \\
\text { matching only pretest-posttest control group design. The subjects } \\
\text { in this study were students of class XI IPA SMA Negeri } 1 \text { Ulubelu. } \\
\text { The effect size hypothesis test is used to obtain the results of the } \\
\text { effectiveness of the PBL model on students' problem solving } \\
\text { abilities. The result of the effect size hypothesis test showed the } \\
\text { value of } 0.68 \text { in the moderate category. So it can be concluded that } \\
\text { the problem-based learning model is effective for improving the } \\
\text { problem-solving ability of high school students. }\end{array}$} \\
\hline Rece & \\
\hline & \\
\hline & \\
\hline Keywords: & \\
\hline $\operatorname{Pr}$ & \\
\hline & \\
\hline & \\
\hline
\end{tabular}

\section{PROBLEM-BASED LEARNING UNTUK MENINGKATKAN KEMAMPUAN PEMECAHAN MASALAH: APAKAH CUKUP EFEKTIF?}

\section{Kata Kunci: \\ Problem-based learning \\ Problem-solving skills \\ Gerak parabola}

\begin{abstract}
ABSTRAK
Penelitian ini bertujuan untuk mengetahui efektifitas model pembelajaran problem based learning terhadap kemampuan pemecahan masalah pada peserta didik SMA. Penelitian ini merupakan jenis penelitian quasy experimental dengan desain the matching only pretest-posttest control group. Subjek dalam penelitian ini adalah peserta didik kelas XI IPA SMA Negeri 1 Ulubelu. Uji hipotesis effecct size digunakan untuk mendapatkan hasil efektifitas model PBL terhadap kemampuan pemecahan masalah siswa. Hasil uji hipotesis effect size menunjukkan nilai 0,68 dengan kategori sedang. Maka dapat disimpulkan bahwa model pembelajaran problem-based learning efektif untuk meningkatkan kemampuan pemecahan masalah pada peserta didik SMA.
\end{abstract}

(C) 2021 Unit Riset dan Publikasi Ilmiah FTK UIN Raden Intan Lampung

\section{INTRODUCTION}

Preliminary research that has been conducted at SMA Negeri 1 Ulubelu, showed that the active role of a teacher is the most important thing in learning, because students really rely on teachers to explore knowledge. This situation causes students to focus only on cognitive aspects and ignore psychomotor and affective aspects. The physics learning process which only emphasizes the cognitive aspects will reduce the nature of physics learning as a process, product, and attitude. Learning that emphasizes the teacher center process is not contextual, oriented only to memorization and makes students not 
accustomed to using higher-order thinking skills. One of the higher order thinking skills is problem solving skills [1]-[4].

Based on the results of interviews with physics teachers, it is known that the teaching and learning process in the classroom has gone well, although there are still many students whose scores are below standard. This problem occurs because learning in the classroom tends to emphasize memorization and ignore the development of students' problemsolving abilities. In fact, one of the goals of learning physics is to create students who can solve complex problems by applying their knowledge and understanding to everyday situations.

To overcome this problem, it is necessary to apply a learning model that can provide meaningful learning to students. One learning model, according to several studies, which is able to provide a meaningful learning experience is a problem-based learning model. Problem-based learning model is a constructivist learning model that emphasizes investigating and building learners' knowledge, and all these activities will be carried out directly by the students themselves, this model can train students' higher-order thinking skills, develop independence, and self-confidence [5]-[9]. Learning should be able to train students in critical thinking and solving problems, so that maximum learning outcomes are achieved. One of the physics learning models that offer this in the process is problembased learning [10][10][5]. Discovery learning model is a learning model in which the learning process does not present a concept that is 'ready to consume', but students are required to organize their own way of learning to find and build a concept [11]-[17]. Problem-based learning model is a learning model that uses problems as a first step to gain new knowledge.

Many studies have proven that problem-based learning models can improve student learning outcomes, including to improve communication skills [18], metacognition [19], science learning outcomes [20], creative thinkign [21], and problem solving [22]. In this study, it will be explained in full how to apply the problem-based learning model and its effectiveness on students' problem-solving abilities.

\section{METHOD}

The method used in this research is a quantitative method with a quasi experimental design. The quasi experimental design used was the matching only pretest-posttest control group design. This research was conducted on two classes selected by nonprobability sampling technique with purposive sampling type. The experimental class is a class that uses a problem-based learning model and a control class that uses a discovery learning model.

The population in this study were all students of class XI at one of the public high schools in Tanggamus, namely SMA Negeri 1 Ulubelu. In this study, two classes were selected, namely class XI IPA 1 and class XI IPA 2. Class XI IPA 1 as an experimental class with a problem-based learning model and class XI IPA 2 using discovery learning learning model.

The problem-solving ability measured in this study is the stage of identifying problems, planning strategies, implementing strategies, and evaluating solutions. These stages are measured using an essay test instrument. The instrument has been validated by 3 expert lecturers and has been tested, which is then analyzed using AnatesV4, the purpose of this analysis is to determine the validity, difference power, level of difficulty, and reliability of the instrument. The instrument of the question consists of 2 main questions, which in the first question consists of 5 sub-questions and in the second question consists of 2 sub-questions. 
Students as subjects will be given a pretest before learning, then do a posttest after the treatment is applied. From the results of the posttest and pretest, the researcher compared the problem solving abilities of students from the posttest and pretest results of each class. The researcher also compared the students' problem-solving abilities between the posttest results in the discovery learning group and the problem-based learning group. The research framework is depicted in Figure 1.

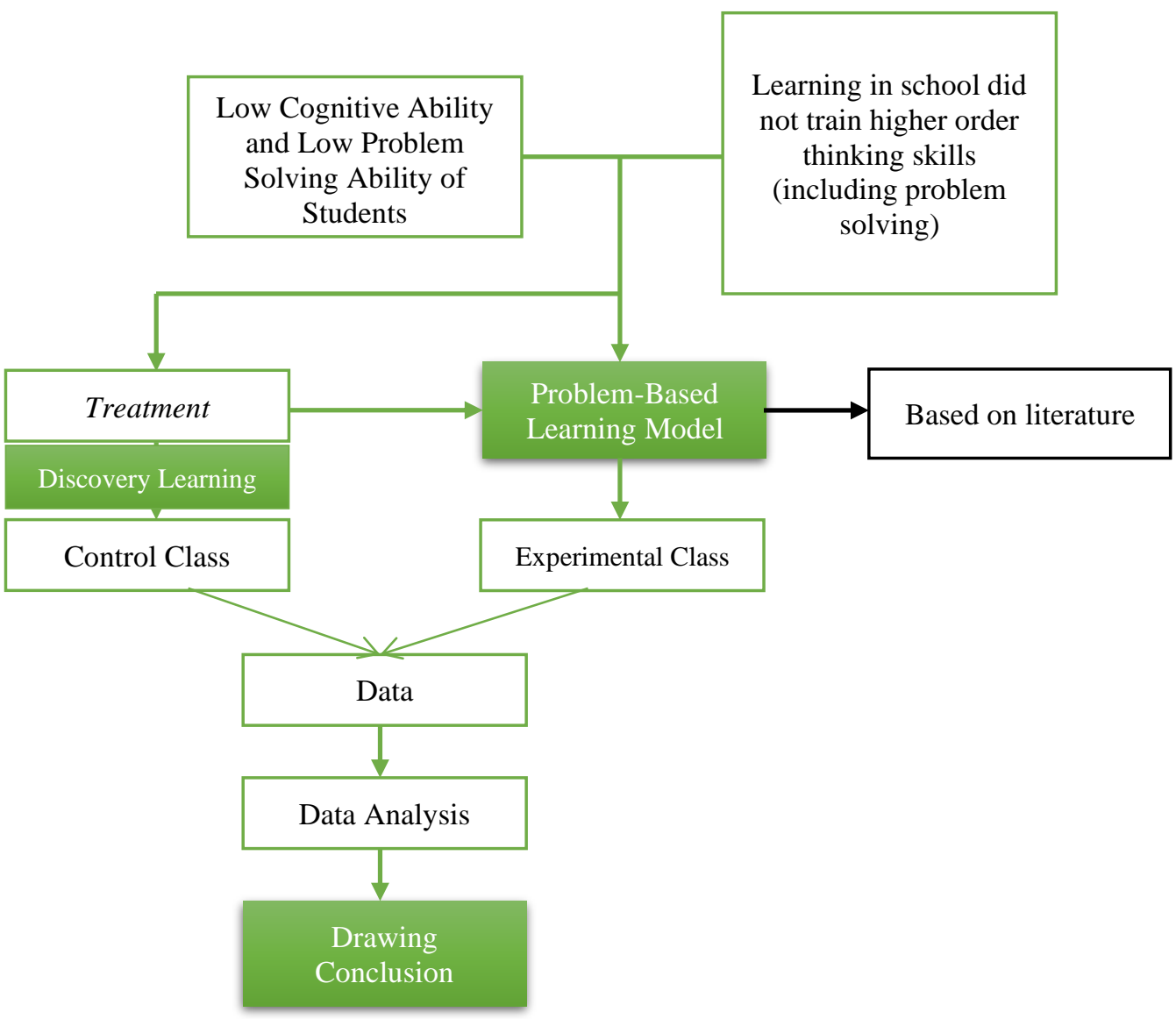

Figure 1. Research Framewor

The data analysis used to determine the effect of the problem-based learning model and discovery learning model on the problem-solving ability of students in this study was statistical data analysis. The data tested were the results of the students' pretest and posttest. A series of preliminary test consists of normality, and homogeneity were done before we do the hypothesis testing. Hypothesis testing using Independent-Sample T Test and effect size test with SPSS 16.0 application program. All these tests, the significance level $(\alpha)$ used is 0.05 or $5 \%$. The criteria for the decisions of all tests are: if Sig. (2-tailed)> 0.05 then $\mathrm{H}_{0}$ is accepted and $\mathrm{H}_{1}$ is rejected, whereas if $<0.05$ then $\mathrm{H}_{0}$ is rejected and $\mathrm{H}_{1}$ is accepted.

The normality test aims to determine whether the sample comes from a normally distributed population or not. To test the normality in this study, the Kolmogorof Smirnov test was used in the SPSS 16.0 program with a significant level of 5\%. If the data is normally distributed, then the variance homogeneity test is then performed. To test homogeneity, this study used the homogeneity of variances test in the SPSS16.00 program with a significant level of 5\%. Hypothesis testing is carried out to analyze the research data, after the normality and homogeneity tests are met, then the hypothesis test is carried 
out. Hypothesis testing is carried out if the data is normally distributed and homogeneous. Hypothesis test used is t-test and effect size test.

\section{RESULTS AND DISCUSSION}

\subsection{The implementation of the Problem Based Learning model and the Discovery Learning model}

Table 1, 2, and 3 show the score of the implementation of learning model.

Table 1. The feasibility of the Learning Model

\begin{tabular}{cccc}
\hline Learning Model & Score & Percentage & Criteria \\
\hline Discovery Learning & 51 & $91,07 \%$ & Excellent \\
Problem Based Learning & 45 & $93,75 \%$ & Excellent \\
\hline
\end{tabular}

Table 2. Pretest and Posttest Scores in Problem Based Learning Class

\begin{tabular}{ccc}
\hline Pretest & Information & Posttest \\
\hline 28,6 & Maximum score & 100,0 \\
20,0 & Minimum score & 37,1 \\
671,4 & Total Score $\left(\sum \mathrm{x}\right)$ & 2111,4 \\
23,2 & Average & 72,8 \\
\hline
\end{tabular}

Table 3. Pretest and Posttest Score in Discovery Learning Class

\begin{tabular}{ccc}
\hline Pretest & Information & Posttest \\
\hline 28,6 & Maximum score & 91,4 \\
20,0 & Minimum score & 37,1 \\
682,9 & Total Score $\left(\sum \mathrm{x}\right)$ & 1682,9 \\
22,8 & Average & 56,1 \\
\hline
\end{tabular}

Tables 1, 2, and 3 show the implementation of the discovery learning model and the problem based learning model in the classroom as assessed by the physics teacher. In fact, the implementation of the two learning models has been assessed with excellent criteria.

After obtaining data from the pretest and posttest activities, then a statistical test is carried out, the goal is to find out whether the data obtained is normally distributed or not. And whether the data obtained is homogeneous or not. Then the statistical data processing was carried out using the SPSS 16.0 application. the results of these statistical tests are shown in tables $4,5,6$, and 7.

Table 4. Normality Test for Problem Based Learning Class and Discovery Learning Class

\begin{tabular}{lcccc}
\hline \multirow{2}{*}{ Statistic } & \multicolumn{2}{c}{ Discovery Learning Class } & \multicolumn{2}{c}{ Problem Based Learning Class } \\
\cline { 2 - 5 } & Pretest & Posttest & Pretest & Posttest \\
\hline Sig. & 0,131 & 0,844 & 0,096 & 0,705 \\
Kolmogorov-Smirnov & Sig $\geq 0,05$ & Sig $\geq 0,05$ & Sig $\geq 0,05$ & Sig $\geq 0,05$ \\
Conclusion & Normal & Normal & Normal & Normal \\
\hline
\end{tabular}

Table 5. Homogeneity Test for Problem Based Learning Class and Discovery Learning Class

\begin{tabular}{lcc}
\hline Statistic & $\begin{array}{c}\text { Pretest Results for Problem Based } \\
\text { Learning Class and Discovery Learning } \\
\text { Class }\end{array}$ & $\begin{array}{c}\text { Posttest Results for Problem Based } \\
\text { Learning Class and Discovery Learning } \\
\text { Class }\end{array}$ \\
\hline $\begin{array}{l}\text { Sig. } \\
\text { Levene's } \\
\text { test } \\
\text { Conclusion }\end{array}$ & 0,771 & 0,357 \\
\hline
\end{tabular}


Table 6. Hypothesis Test for Problem Based Learning Class and Discovery Learning Class

\begin{tabular}{lcc}
\hline \multicolumn{1}{c}{ Hypothesis Test: Independent-Sample T Test } & Pretest & Posttest \\
\hline Criteria & Sig.(2-tailed) $\geq 0,05$ & Sig.(2-tailed) $<0,05$ \\
Sig.(2-tailed) & 0,549 & 0,000 \\
Decision & $H_{0}$ is accepted & $H_{1}$ is accepted \\
\hline
\end{tabular}

Table 7. Effect Size Test in Problem Based Learning Class and Discovery Learning Class

\begin{tabular}{ccccc}
\hline \multicolumn{1}{c}{ Class } & Average & Standard Deviation & Effect Size & Criteria \\
\hline Discovery Learning & 33,3 & 179,5 & $-0,68$ & Moderate \\
Problem Based Learning & 49,6 & 390,8 & $-0,8$ & \\
\hline
\end{tabular}

Based on the research results presented in tables 2 and 3, the pretest results for the experimental class and the control class had a difference in scores of 0.4 . The hypothesis test also shows that the pretest value has a Sig. (2-tailed) of 0.549 , that means the value of Sig. (2-tailed) $\geq 0,05$ that is, the average pretest value of each class can be said to be the same or the prior problem solving ability of students in both classes is the same, before the treatment is applied.

After the application of the learning model is carried out in each class, a posttest is given to measure the problem solving ability in each class. The posttest items are the same questions as the pretest. Hypothesis test results show sig. (2-tailed) 0,000, with the number sig. (2-tailed) $<0,05$ and the average posttest scores on the discovery learning class and the problem based learning class are 56.1 and 72.8 , thus there is a significant difference between the problem based learning class and the discovery learning class. It shows that learning using the problem-based learning model improves the problem-solving ability of students better than the discovery learning model does.

In the effect size test table, an effect size value of -0.68 is shown, the minus sign (-) indicates that the experimental class with the problem-based learning model has a more significant increase in problem-solving abilities than the control class with the discovery learning model.

The results of this study were supported by the results of research conducted by Umi Supraptinah, Budiyono, and Sri Subanti, who stated that the PBL model with a scientific approach was able to improve mathematical problem solving abilities better than the Discovery Learning and TTW models. [4]. The increase in problem-solving abilities in students is because the PBL model allows students to increase independence in thinking and analyzing problems. The ability to analyze problems causes students to be able to solve problems. This opinion is in line with Gagne's opinion that "problem-solving ability is a set of procedures or strategies that allow a person to increase independence in thinking". Moreover, in the next stage the teacher carefully evaluates the correct answers, to be refined with the concept of the problem. Thus, tutoring can improve problem-solving skills in learning. This opinion is in line with the opinion of Abu Ahmadi "tutoring is a process of providing continuous and systematic assistance to individuals in solving problems they face to improve student learning outcomes" [6]. Problem Based Learning (PBL) is a learning approach that uses real-world problems as a context for students to learn about critical thinking and problem-solving skills, as well as to acquire essential knowledge and concepts from course materials or subject matter [3].

Based on previous studies and research conducted by researchers, it shows that the problem-based learning model is better than the discovery learning model in improving the problem-solving abilities of students. The learning process using PBL should be more optimal if the teacher provides or facilitates students with various references, because this will make it easier for students to determine the best solution to solve problems [6]. 


\subsection{Research Findings}

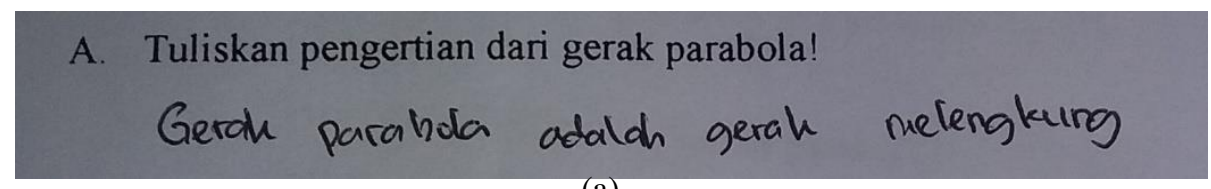

(a)

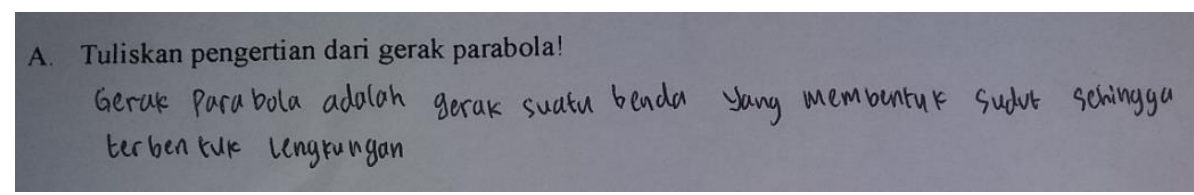

(b)

Figure 2. Student Worksheet Results for Point A (a) Discovery Learning Class and (b) Problem Based Learning Class

Based on the research findings, when students in the discovery learning class worked on their student worksheets, they answered the questions in point A incorrectly, as shown in Figure 2 (a). But different things are shown in the problem-based learning class, students can answer questions more complexly, as shown in Figure 2 (b), and the answers written are more precise than students' answers from discovery learning classes. The same thing was shown when answering point B, as shown in Figures 3 (a) and (b).

\section{B. Apakah penyebab dari adanya gerak parabola?}

$$
\text { Adanya Gaya }
$$

(a)

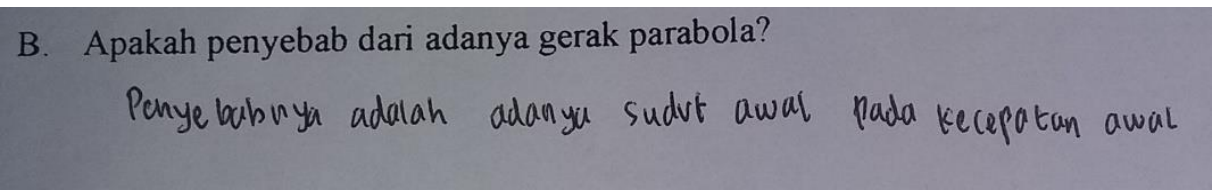

(b)

Figure 3. Student Worksheet Results for Point B, (a) Discovery Learning Class and (b) Problem Based Learning Class

The difference in results is because in learning with the PBL model, students are required to be actively involved in learning, a process based on problems in everyday life also makes students think that learning feels fun, students become more aware of the scientific reasons for the phenomena they often experience. in daily life. Thus, students' scientific activities in the learning process will affect the development of their psychomotor aspects. The Problem Based Learning model can change students from receiving passive information to being active (student centered). This model allows students to acquire new knowledge in problem solving. In Problem Based Learning, student attitudes such as problem solving, thinking, group work, communication and information develop positively. 


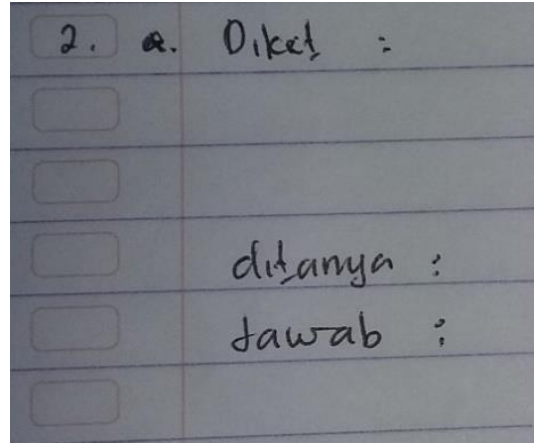

(a)

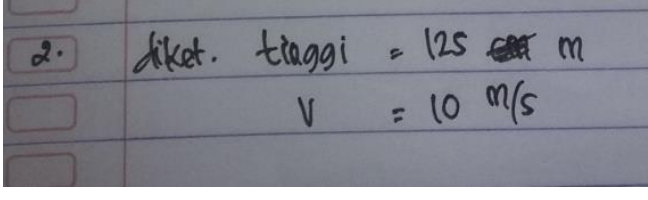

(b)

Figure 4. Student Pretest Results, (a) Discovery Learning Class and (b) Problem Based Learning Class

Based on the results of the pretest that has been carried out in Figure 3, it can be seen that students in problem-based learning classes tend to solve problems systematically based on the stages of problem solving. Whereas in the discovery learning class, no solving ability stage has yet been fulfilled, it can be said that the initial solving ability of the problem-based learning class students is better than that of the discovery learning class students.

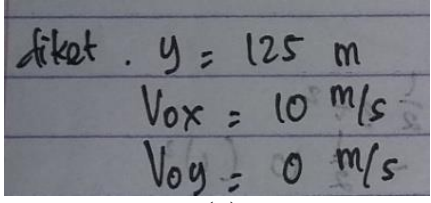

(a)

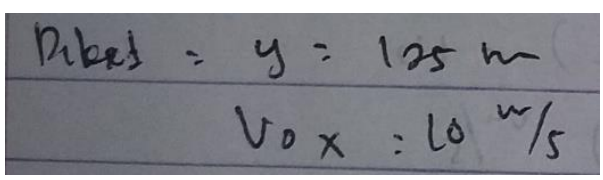

(b)

Figure 5. Student Posttest Results, (a) Discovery Learning Class and (b) Problem Based Learning Class

The results of the posttest show that the results of students' problem solving in each class, the discovery learning class and the problem-based learning class, show that they have mastered the problem identification stage.

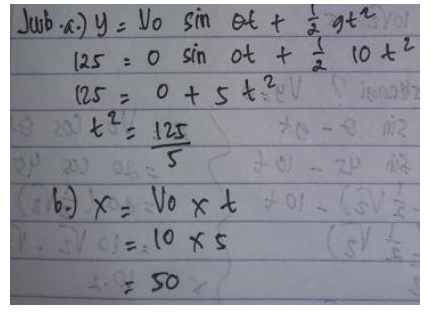

(a)

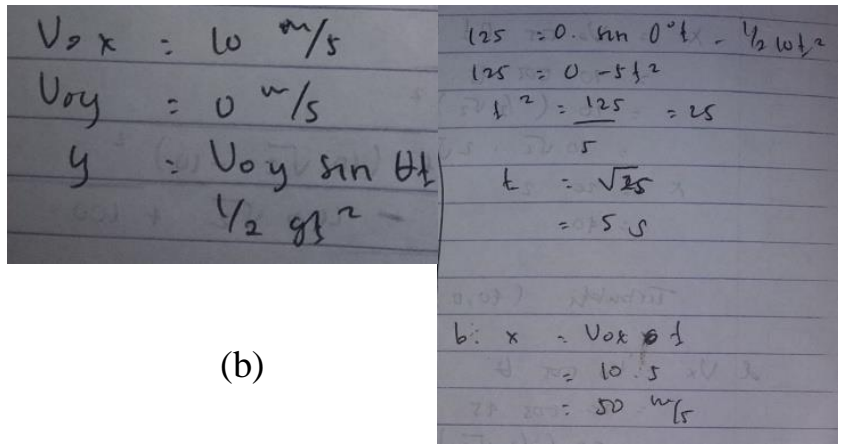

(b)

Figure 6. Student Posttest Results, (a) Discovery Learning Class and (b) Problem Based Learning Class

In Figure 6, it is a question to measure the ability to plan and implement strategies, it can be seen that the two students from the discovery learning class and the problembased learning class have mastered it well. At the strategy planning stage, students are able to write down the equations that will be used in solving the problem, while in the strategy implementation stage, students are able to substitute the magnitude into the equation. The final problem-solving stage according to Young and Freedman and Heller et al is evaluating the solution. In evaluating the solution, students in the experimental class have 
been able to fulfill it, namely by writing the correct unit for their answer. Whereas in the control class (discovery learning), students were not able to write down the right units for their answers, so students only reached the stage of implementing the strategy. So, in the problem-based learning class, students are able to fulfill all stages of problem-solving abilities, namely the stage of recognizing the problem by writing the known quantities, the stage of planning a strategy by determining the right equation, the stage of implementing a strategy by substituting the quantity value into the equation. And the last stage is evaluating the solution by evaluating the unit. Accordingly, it can be said that the final problem solving ability of problem based learning class students is better than the ability of discovery learning class students.

In this study, it was revealed that PBL had a positive effect on learning outcomes, namely the ability to solve problems and be effective in improving it. This is in line with the claims of previous research, that the PBL model has a positive effect on students' physics learning achievement. The application of the PBL model that presents real problems can increase knowledge and understanding, and can hone problem solving skills, which then has a positive impact on improving student learning outcomes. This is in line with research conducted by Purnamaningrum which states that the PBL model can improve students' creative thinking skills. In line with the research conducted by Pronoto, it was stated that there were differences in the activeness values of students who studied with the problem-based learning model and those who studied with guided discovery learning. PBL provides more opportunities for students to be active and take independent initiatives in completing tasks during learning [25]. Slamet Rochmad Nurochim's research states that the application of the Problem Based Learning model is more effective in improving student learning outcomes than the discovery learning model [7], good learning outcomes are the impact of good problem solving skills.

The reasons why PBL is suitable for developing problem-solving abilities can be seen in the Table 8 [8].

Table 8. The Relationship of Problem Based Learning Learning Model with Problem Solving Indicators

\begin{tabular}{lll}
\hline No & \multicolumn{1}{c}{ PBL Stages } & \multicolumn{1}{c}{ Problem Solving Indicators } \\
\hline 1 & Problem orientation & Understanding the Problem \\
2 & Organizing students & Planning Problem Solving \\
3 & Individual and group investigations & Planning Problem Solving \\
4 & Develop and present the work & Solve the problem \\
5 & Analyzes and evaluates the problem-solving process & Solve the problem \\
\hline
\end{tabular}

The application of the Problem Based Learning (PBL) learning model makes students more prepared to solve problems. The fact of this increase is supported by the results of research conducted by Utama Dewi which shows that the Problem Based Learning (PBL) model is able to accommodate students' problem solving abilities. When compared with students who learn with the Direct Instructions (DI) model, of course students who learn with the PBL model will be superior in their ability to solve problems. Problem Based Learning (PBL) can improve problem-solving skills because PBL is a model that is oriented to real-life problems that require students to be able to solve existing problems. Students are required to use their thinking skills [9]. Students who get the PBL learning model experience an increase in better problem-solving abilities [10]. Problembased learning has a positive influence on critical thinking dispositions and perceptions of problem-solving abilities [11]. The improvement of students' problem-solving abilities through learning with the PBL model is also presumed because the PBL model is based on the principle that students not only acquire knowledge, but also know how to apply this 
knowledge in real situations [12]. Another study which also supports the finding of this research states that the increase in the mathematical problem solving ability of students with PBL is classified as high [13].

\section{CONCLUSION}

Based on the finding of this research, we can conclude that: there is an average difference in the results of problem-solving abilities between the discovery learning model class and the problem-based learning model class on the subject of projectile motion. The application of the problem-based learning model is more effective in increasing the problem-solving ability than the application of the discovery learning model. Based on the research that has been done, it is recommended for teachers to use a more varied learning model when learning so that learning can be more fun and directed. For other researchers it is expected to examine the effectiveness of using problem based learning models with different learning topics.

\section{REFERENCES}

[1] M. Sayyadi, A. Hidayat, and Muhardjito, "Pengaruh Strategi Pembelajaran Inkuiri Terbimbing dan Terhadap Kemampuan Pemecahan Masalah Fisika pada Materi Suhu dan Kalor Dilihat dari Kemampuan Awal Siswa," J. Inspirasi Pendidik., vol. 6, no. 2, pp. 352-364, 2016.

[2] G. Gunawan, A. Harjono, H. Sahidu, L. Herayanti, N. M. Y. Suranti, and F. Yahya, "Using Virtual Laboratory to Improve Pre-service Physics Teachers' Creativity and Problem-Solving Skills on Thermodynamics Concept," J. Phys. Conf. Ser., vol. 1280, no. 5, 2019, doi: 10.1088/1742-6596/1280/5/052038.

[3] M. Hasanah and E. Surya, "Difference in the Abilities of Creative Thinking and Problem Solving of Students in Mathematics by Using Cooperative Learning and Learning ofProblem Solving,” Int. J. Sci. Basic Appl. Res., vol. 34, no. 1, 2017.

[4] A. Panaoura, P. Michael-Chrysanthou, A. Gagatsis, I. Elia, and A. Philippou, "A Structural Model Related to the Understanding of the Concept of Function: Definition and Problem Solving," Int. J. Sci. Math. Educ., vol. 15, no. 4, pp. 723 740, 2017, doi: 10.1007/s10763-016-9714-1.

[5] M. A. Rasyid, "Profil Berpikir Reflektif Siswa SMP dalam Pemecahan Masalah Pecahan Ditinjau dari Perbedaan Gender," Kreano, J. Mat. Kreat., vol. 8, no. 2, pp. 171-181, 2017, doi: 10.15294/kreano.v8i2.9849.

[6] S. Psycharis, "Examining the effect of the computational models on learning performance, scientific reasoning, epistemic beliefs and argumentation: An implication for the STEM agenda," Comput. Educ., vol. 68, pp. 253-265, 2013, doi: 10.1016/j.compedu.2013.05.015.

[7] M. Suryani, L. H. Jufri, and T. A. Putri, "Analisis Kemampuan Pemecahan Masalah Siswa Berdasarkan Kemampuan Awal," Musharafa J. Pendidik. Mat., vol. 9, no. Januari, pp. 119-130, 2020.

[8] R. Sundayana, "Kaitan antara Gaya Belajar, Kemandirian Belajar, dan Kemampuan Pemecahan Masalah Siswa SMP dalam Pelajaran Matematika," Mosharafa J. Pendidik. Mat., vol. 5, no. 2, pp. 75-84, 2018, doi: 10.31980/mosharafa.v5i2.262.

[9] L. E. Castro-Fajardo, A. Santamaria, K. L. Bernal-Hernandez, F. A. GomezHernandez MG, and M. C. Garrcia-Cepero, "How Do Education Professionals Understand Creativity? A Study of The Implicit Theories On Creativity In A Sample Of Educators," J. Educ. Young Sci. Gift., vol. 2, no. 2, pp. 41-41, 2015, doi: 10.17478/jeysg.201429020. 
[10] N. Sulistyowati, T. W. Antonius, and S. Woro, "Efektivitas Model Pembelajaran Guided Discovery Learning Terhadap Kemampuan Pemecahan Masalah Kimia," Universitas Negeri Semarang, 2012.

[11] H. Ardiansyah, "Pengaruh Metode Pembelajaran Brainstroming terhadap Kemampuan Berpikir Kritis berdasarkan Kemampuan Awal Peserta Didik Hamdan," Indones. J. Econ. Educ., vol. 1, no. 1, pp. 31-42, 2018, doi: 10.17509/jurnalijee.

[12] B. Tompo, A. Ahmad, and M. Muris, "The development of discovery-inquiry learning model to reduce the science misconceptions of junior high school students," Int. J. Environ. Sci. Educ., vol. 11, no. 12, pp. 5676-5686, 2016.

[13] W. Widiadnyana, W. Sadia, and W. Suastra, "Pengaruh model discovery learning terhadap pemahaman konsep IPA dan sikap ilmiah siswa SMP," J. Progr. Pascasarj. Univ. Pendidik. Ganesha, vol. 4, no. 1, pp. 1-13, 2014.

[14] W. Wartono, M. N. Hudha, and J. R. Batlolona, "How are the physics critical thinking skills of the students taught by using inquiry-discovery through empirical and theorethical overview?," Eurasia J. Math. Sci. Technol. Educ., vol. 14, no. 2, pp. 691-697, 2018, doi: 10.12973/ejmste/80632.

[15] H. Y. Purnomo, Mujasam, and I. Yusuf, "Penerapan Model Guided Discovery Learning pada Materi Kalor terhadap Hasil Belajar Kognitif Peserta Didik Kelas VII SMPN 13 PRAFI Mobokwari Papua Barat," Pancaran, vol. 5, no. 2, pp. 1-14, 2015

[16] K. W. B. Putra, I. M. A. Wirawan, and G. A. Pradnyana, "Pengembangan E-Modul Berbasis Model Pembelajaran Discovery Learning Pada Mata Pelajaran 'Sistem Komputer' Untuk Siswa Kelas X Multimedia Smk Negeri 3 Singaraja,” J. Pendidik. Teknol. dan Kejuru., vol. 14, no. 1, pp. 40-49, 2017, doi: 10.23887/jptk.v14i1.9880.

[17] Sucipta, E. Ahman, and N. Budiwati, "Metode Guided Discovery Learning terhadap Tingkat Berpikir Kritis Siswa Dilihat dari Motivasi Belajar," Indones. J. Econ. Educ., vol. 1, no. 1, pp. 1-8, 2018, doi: 10.17509/jurnal.

[18] N. W. Ashari and Salwah, "Problem Based Learning (PBL) Dalam Meningkatkan Kecakapan Pembuktian Matematis Mahasiswa Calon Guru," J. Mat. dan Pendidik. Mat., vol. 2, no. 2, pp. 100-109, 2017.

[19] M. Kuvac and I. Koc, "The Effect of Problem-based Learning on The Metacognitive Awareness of Pre-service Science Teachers," Educ. Stud., pp. 1-21, 2018.

[20] P. Rini, "Efektivitas Model Problem Based Learning dalam Mereduksi Disparitas Gender pada Capaian Pembelajaran Sains," J. Ilm. Pendidik. Fis. Al-Biruni, vol. 6, no. 1, p. 57, 2017.

[21] A. Elizabeth and M. M. Sigahitong, "Pengaruh Model Problem Based Learning Terhadap Kemampuan Berpikir Kreatif Peserta didik," Juranal Pengkaj. Ilmu dan Pembelajaran Mat. dan IPA IKIP Mataram, vol. 6, no. 2, 2018.

[22] Yuberti, S. Latifah, A. Anugrah, A. Saregar, Misbah, and K. Jermsittiparsert, "Approaching Problem-Solving Skills of Momentum and Impulse Phenomena Using Context and Problem-Based Learning," Eur. J. Educ. Res., vol. 8, no. 4, pp. 1217-1227, 2019, doi: 10.12973/eu-jer.8.4.1217.

[23] E. Sujarwanto, H. A, and Wartono, "Kemampuan Pemecahan Masalah Fisika Pada Modeling Instruction Pada Peserta didik SMA Kelas XI," Universitas Negeri Malang, 2014.

[24] U. Supraptinah, Budiyono, and S. Sri, "Eksperimentasi Model Pembelajaran Discovery Learning, Problem Based Learning, dan Think-Talk-Write dengan Pendekatan Saintifik Terhadap Kemampuan Pemecahan Masalah Matematika 
Ditinjau dari Kemandirian Belajar Pes," Universitas Sebelas Maret, 2015.

[25] H. Pranoto and S. Slamet, "Perbandingan Model Pembelajaran Problem Based Learning dan Guided Discovery Learning terhadap Keaktifan Siswa Kelas X SMA," Universitas Sebelas Maret, 2017. 